\title{
Addressing The Challenge of Building Research Capabilities in Business Management Undergraduate Students
}

\author{
Martin Rich, Ann Brown and Aneesh Banerjee \\ Cass Business School, London, UK \\ a.p.brown@city.ac.uk \\ m.g.rich@city.ac.uk \\ aneesh.banerjee@city.ac.uk \\ DOI: 10.34190/JBRM.17.3.003
}

\begin{abstract}
The research process is complex, involving many conceptually different steps that require a variety of skills. For instance, early on in the research process the task of identifying and articulating a suitable research problem often involves, amongst other skills, a high level of creativity and critical thinking, whereas later on in the process, application of a suitable research method would require deep knowledge of the state of art in that methodology. As the techniques used by researchers to iterate between current discipline theory, subject knowledge and research methodology gets increasingly specialized, it is also becoming more opaque to people outside the research community. Management students with little or no exposure to research find this puzzling because they are being encouraged to do something creative and original, and at the same time they are expected to build on existing knowledge using a set of conventions associated with the chosen methodology. Business students in their 1st year face many new situations. Most of them have little experience of what research is about or the various elements that are necessary for a successful project. The teaching at school level mostly focuses on imparting subject knowledge and instilling basic numeracy and literary skills. It does not prepare them so well for setting their own goals and working independently - the core of research. Traditional teaching methods can help them acquire the relevant subject knowledge and basic research methods. But putting these together in a piece of practical research requires in depth understanding and creative thinking. Problem-based learning (PBL) is a way to help UG students at the beginning of their research attempts to develop the mindset and skills needed. This paper makes the case for introducing Critical Thinking skills to Business Management students in their 1st year, using a problembased Learning (PBL) approach. It assesses what was involved in developing and delivering such a course. Both staff and students found the experience challenging, but the overall response was positive establishing that the approach taken was fundamentally effective.
\end{abstract}

Keywords: Problem-based learning, teaching research methods, first year UG business students, business research process

\section{Introduction}

Business Management Students arrive at university with little knowledge of the subject of management or research methods. By the last year of their degree they will be expected to carry out their own individual piece of research. On completion of their degree they will be expected to be ready for a managerial job. Both activities call for subject knowledge and a range of business and personal skills, all of which will be unfamiliar to first year business management students. Many will opt to take graduate studies, or after a period of work based experience return to University. A knowledge of research methods will then be especially important.

Management as a discipline is multi-faceted drawing on a number of related disciplines. The extra-ordinary high rate of change in new business and management ideas and the amazingly high turnover in firms ensures that subjects of interest to executives (and hence researchers) expand and change at just as fast a rate. The research process itself is complex, involving many conceptually different steps. Despite well documented descriptions of the various ways it is possible to structure the research process, there is always a need for innovative and independent thinking in any research project. Each management research project is a unique piece of work. Successful completion requires the researcher to have a number of personal skills of which logical and critical thinking are probably the most significant.

The various disciplines that contribute to management theory also provide management researchers with a wide range of potential research methodologies, involving differing types of thinking and analysis. The fledgling management researcher needs both knowledge of these methods and the skills to apply them effectively. 
Most first year students come directly from the well-structured learning environment of school, and will have had little experience of practising these type of personal skills or of taking control of their own learning. To some extent, it has been assumed that undergraduate students acquire the skills of critical thinking as a result of being exposed to the traditional structure of university teaching of lectures and individual and student group coursework assignments. But the continuing complaints of business leaders as to the lack of these skills (among others) in new graduates suggests that this is not the case. With the recent redesign of the business management undergraduate degree, Cass has taken the opportunity to add a module specifically designed to help students develop critical thinking skills, based on constructivist teaching methods.

This paper makes the case for introducing Critical Thinking skills to Business Management students in their $1^{\text {st }}$ year, using a problem-based Learning (PBL) approach. It also aims to explain what was involved in developing and delivering such a course and assesses the results of the first year. Section 2 identifies some of the key skills needed for research in management The following section establishes the new intake of undergraduates' relative lack of experience or understanding of them (section 3). In section 4, the paper introduces the PBL approach to teaching and establishes both the potential value of such an approach and the challenge of designing and delivering one. The experience of using this method in teaching critical thinking skills in the first term of the first year of the redesigned business management undergraduate degree at Cass Business School is described in section 5 .

\section{The Business and Management Research Process}

What constitutes the discipline of management is a contentious topic. As an activity now carried out by most of the population at some level we all have views on what it is and how best to do it. Professional managers, who are responsible for managing business tend to rely on theory and knowledge created from business school research only if it is useful in meeting their professional objectives - be it managing the relatively 'hard' operational problems or the 'softer' people related concerns. This provides a distinctive focus for the management researcher (Easterby-Smith et al, 1995; Easterby-Smith et al, 2018). This section describes what is required for each of the main steps in the research process and presents the key characteristics of management research that researchers need to address.

Business Schools have been developing and teaching business and management theory for over a century, drawing on knowledge and ideas developed in a wide range of different but related disciplines such as statistics, economics, social science and psychology (Boddy, 2017; Easterby-Smith et al, 2018). Practitioners business managers have been learning, applying and criticising much of the theory for almost as long these fields have existed. Business organisations are continually innovating in product or service provision, culture and jobs, organisational structure and training. This provides a rich ever changing field for research, challenging existing theory, proposing new theory and above all researching actual practice. From the point of view of a management researcher, the focus on practical relevance of research results leads to an emphasis on empirical work. The changing business scene offers scope for original case material. But the central two factors of management - an organisation's operations and the people working within it, dictates the importance of researchers making use of other disciplines ideas. This offers an ever expanding range of research methods developed by other disciplines that management researchers can and are expected to use.

The research process is usually presented as a sequence of between seven and ten distinct stages all of which must be completed for any piece of research to be credible (see Table 1 for a typical list) (Saunders et al, 2015). It is easy to get lost in the welter of detail required to successfully carry out the individual steps. By taking each step separately, Business Research methods text books (Saunders et al, 2015; Bryman and Bell,2015; Easterby-Smith et al, 2018), lectures, classes and workshops tend to support this outcome. But it is not a linear process. Researchers will iterate between these steps, perhaps revisiting various stages many times, as their understanding of the research problem develops and changes as a result of the findings from other steps such as data analysis and writing up. As table 1 shows, choices are involved at every step, but these are not independent of each other. The final decisions must ensure that the work carried out at each stage forms part of an integrated whole, both supporting and consistent with work carried out at all other stages. It is by writing up the work as it progresses that the researcher develops a more profound understanding of the contribution of each step. This deepening understanding may be one of the triggers for a rethink of work carried out at other perhaps previous stages. The process of writing up is critical to the project (Saunders et al, 2015) - for the researcher in progressing the work and for the ultimate audience in explaining what has been 
done, why it has been done and what has been found out. Writing skills are tested at every stage of the research process.

Table 1: The steps in empirical research and what they involve(based on authors' experience, Saunders et al, 2015)

\begin{tabular}{|c|c|}
\hline Step & Required Knowledge, understanding, skills and Mind-set \\
\hline $\begin{array}{l}\text { Choice of Subject area of research } \\
\text { and nature of problem area }\end{array}$ & $\begin{array}{l}\text { Knowledge of subject deep enough to outline general nature of problem topic that } \\
\text { interests you. }\end{array}$ \\
\hline $\begin{array}{l}\text { Extensive Literature review of } \\
\text { subject area research and current } \\
\text { accepted theories with close } \\
\text { attention to recent published work }\end{array}$ & $\begin{array}{l}\text { Up to date Knowledge of research in the subject area(s); Knowledge acquisition; } \\
\text { mastery of detail; organisation and structuring of the literature to focus on the } \\
\text { research question and support choices made at each subsequent step. }\end{array}$ \\
\hline $\begin{array}{l}\text { Development of Research Question } \\
\text { (RQ) }\end{array}$ & $\begin{array}{l}\text { Understanding of the problems posed by the subject area; Creative development of } \\
\text { a doable and relevant } R Q \text {, outline of expected type of results aimed for }\end{array}$ \\
\hline $\begin{array}{l}\text { Choice of Philosophy of research; } \\
\text { epistemology, ontology }\end{array}$ & $\begin{array}{l}\text { Knowledge of range of options; choice of approach consistent with } R Q \text {, clarifying } \\
\text { your personal worldview; implications for methodology to be applied }\end{array}$ \\
\hline $\begin{array}{l}\text { Research method chosen and } \\
\text { reasons for choice }\end{array}$ & $\begin{array}{l}\text { Up to date knowledge of range of research methodologies appropriate for business } \\
\text { research; critical assessment of these methods, choice made consistent with RQ } \\
\text { and results aimed for, reasons for choice }\end{array}$ \\
\hline $\begin{array}{l}\text { Overall Design of the research } \\
\text { project - choice of data collection } \\
\text { methods, analysis appropriate for } \\
\text { chosen research method, reasons } \\
\text { for choice }\end{array}$ & $\begin{array}{l}\text { Mastery of the rules governing the application of the chosen research method; } \\
\text { Mastery of Rules governing collection of the type of data being collected; critical } \\
\text { assessment of reasons for choice of methods }\end{array}$ \\
\hline Data Collection implementation & $\begin{array}{l}\text { Knowledge of data collection potential problems; ways to manage problems and } \\
\text { obtain good quality data }\end{array}$ \\
\hline $\begin{array}{l}\text { Choice of methods of Analysis of } \\
\text { data; reasons and implementation }\end{array}$ & $\begin{array}{l}\text { Mastery of appropriate methods of analysis; study of patterns revealed by the data; } \\
\text { creative interpretation and comparison to similar work }\end{array}$ \\
\hline $\begin{array}{l}\text { Presentation of Results and } \\
\text { interpretation }\end{array}$ & $\begin{array}{l}\text { Insight and creativity in combining both results of data analysis and context of } \\
\text { problem; critical assessment of the power of the analysis and results }\end{array}$ \\
\hline $\begin{array}{l}\text { Assessment of Contribution to } \\
\text { knowledge }\end{array}$ & Subject area knowledge; critical assessment of work \\
\hline $\begin{array}{l}\text { Assessment of Limitations and } \\
\text { further research that looks promising }\end{array}$ & Critical assessment of work; creativity in outlining future possibilities \\
\hline
\end{tabular}

A number of characteristics of this type of work emerge from the analysis shown in the table:

- The myriad choices required, establishes that each project is a unique piece of independent work ; each piece of research poses problems for which there is not necessarily a routine or obvious solution

- The need for innovation and creativity as well as subject knowledge and the researcher's skills in applying the well-defined rules governing the steps in the research process.

- All decisions require justification through critical assessment of alternatives and explanation of the basis for the choices made. This challenges the researcher's ability for reflection and selfassessment.

- The need for clear thinking throughout the process so that the final report and presentations can show a coherent, logical structure that makes sense.

Hence, although knowledge of the range of research methodologies and the subject knowledge are of great importance, the personal skills of the researcher in applying these theories are just as important. These include the ability to work independently setting own goals, to think in a clear, logical and critical way and to communicate the results effectively.

\section{The Business Management degree and Critical Thinking skills}

Critical Thinking plays an important role in a business students' life - both while on the degree and after completion, in their careers. The research project that is a key component of most degrees requires these type of skills (as section 2 has established). The degree is designed to prepare undergraduate students for a 
career in management and hence embraces a wide range of disciplines encompassing conflicting theories, with differing pedagogic approaches and widely varying types of assignments. This poses a challenge in integrating these disparate elements into a coherent body of knowledge, for which clear, organised and critical thinking is an important tool for students. Moreover employers and business organisations have been vocal in their demands for graduates with critical thinking skills.

The students' level of preparedness to acquire knowledge in a complex and nuanced manner is frequently limited. Their educational background prepares them well for knowledge acquisition, but not for dealing with the conflicting theories presented to them by their university teachers. Typically they have come from a school syllabus which focuses on clearly defined areas of knowledge and provides limited training in how to research matters for themselves. O'Donovan (2010) observed that a significant proportion of $1^{\text {st }}$ year students saw knowledge purely in terms of a set of uncontested facts to be memorised, and noted behaviours and attitudes that mirrored this conception. She found that $1^{\text {st }}$ year students frequently focused their efforts on memorising notes, recalling uncontested facts, and viewing the lecturer as an authority. Students at this stage were often puzzled by lecturers presenting them with multiple conflicting views of a situation. A further observation is that students often expressed negative views about particular activities within the $1^{\text {st }}$ year, because these activities did not accord with their expectations of having knowledge transmitted to them. Because management is such a diffuse subject embracing a range of constituent disciplines, it does not logically follow from any subject taught before the age of 18 , except arguably business studies. Hence students arrive having studied a very broad range of subjects during the last few years of their time at school. Some arrive with a high level of existing knowledge in, for example, statistics or economics whereas others have little or no knowledge of them. To participate effectively in the later stages of the degree students need to have a thorough grounding in these subjects as well as having effective study skills. So a significant component of the $1^{\text {st }}$ year is devoted to imparting knowledge in a didactic manner. Moreover each sub-discipline in management is best suited to a different pedagogic approach. Both the pedagogic techniques and the expectations held by students of how they can be taught vary considerably across the content within a Business Management degree. From a student's perspective the $1^{\text {st }}$ year can come across as a set of disjointed set of subjects with no clear unifying theme and no common approach to delivery of the material.

Maunder et al (2013) discuss the transition to university and set out to understand the university experience in its entirety. While their analysis extends to students' perception of their status as university students, and their tendency to form social groups with one another, they also note students' need to participate in independent learning as something that distinguishes university from earlier stages of study. Furthermore they stress that the transition continues to have an impact beyond the first year of an undergraduate course.

As noted by Robinson et al (2013) there is an imperative to provide first year students with feedback which supports this transition. The notion of threshold concepts (Land, 2016) refers to ideas and approaches which can be difficult for students to grasp, but which have the potential to move a student forward within a transformational process. Land illustrates this by pointing out that a common cause of errors made by experts in many fields is that they apply knowledge which would have been appropriate to a previous set of circumstances. He extends this to the student experience by suggesting that students are often limited because they apply knowledge, and acquire knowledge, using techniques that were appropriate while they were still at school. This is part of the argument for students to be encouraged to persevere with 'troublesome' ideas which, while uncomfortable in some ways, can encourage students to think in a way more appropriate to degree-level study. Moreover it is important that they start this process as early as possible in their first year.

The World Economic Forum report on the 'Future of Jobs' published in 2018 (WEF, 2018) identified the high level of change in the world of work expected within the next 5 years. A key finding was the reskilling imperative required by 2022 for over $50 \%$ of the workforce. They highlighted the growing need for 'human skills such as creativity, originality, critical thinking, persuasion and negotiation', which they forecast to be in ever greater demand in the future. Barnett and Hallam (1999) support this finding, in their analysis of the requirements placed upon higher education by a world of 'supercomplexity', stressing the need to emphasise learning processes more than student outcomes. They observe that, while academics frequently espouse the value of critical thinking, they do not always build effective practice that fosters critical thinking among students. Alex Wright in the Times Higher Education journal (THE, 2019) concurs on the lack of critical thinking skills exhibited by both academic staff and students. These findings provide a strong argument for building a 
module directed at developing the skills of critical thinking (Chatfield, 2018) and reflection into the $1^{\text {st }}$ year of Business Management courses.

\section{Activity based teaching and Problem Based Learning (PBL)}

Skills are often acquired through practice. It takes time and effort to first acquire and then develop a skill to a high level of expertise (Dreyfus and Dreyfus,1988). Some skills (for example solving mathematics problems) are best learnt by practice on text book exercises, worked in the classroom. First year students are experienced and generally proficient at these types of skills. The 'Soft skills' of dealing with other people cannot be learnt this way. For example, Linda Hill (1992) established that the most effective way of learning to be a manager was by the actual experience of doing the job. This somewhat hit or miss way of learning is costly and time consuming. Hence educationalists have sought to accelerate the process by creating practical activities that give students the chance to practice the required skills, within an academic or training environment. This is then combined with the provision of various forms of appropriate feedback. More broadly, Goodyear and Dimitriadis (2013) argue for application of 'activity-centred design' which takes a student-oriented perspective.

This reflects a long-term trend from transmissive pedagogies, which are focused on knowledge flowing in one direction from lecturers to students, to constructivist pedagogies. In a business school where a significant proportion of students have some relevant pre-existing knowledge and experience, the constructivist approach is particularly worthwhile.

\subsection{Problem-based learning (PBL)}

Problem-based learning (PBL), the approach used for the new module described below, is a constructivist pedagogy. It is particularly appropriate for teaching the subject discipline of critical thinking as the method itself creates the conditions in which the skills of critical thinking are developed (Smith, 2005; Ungaretti et al, 2015; Schmidt et al, 2009; Loyens et al, 2011; Thomas 2009; Ozturk et al, 2005). It is a student-centred method of learning in which students learn by doing. Students are presented with a real life problem similar to those they will face in their work. They spend most of the course sessions working in small discussion groups addressing the given case questions. The key differentiator from other forms of activity based learning is the nature of the problem. This is chosen or designed to be complex and ill-structured with no right answer. The problem case is set within a realistic context relevant to the subject discipline theory to be taught (Loyens et al, 2011; Dolmans et al, 1997). The student discussion groups, need to make up their minds about how they would manage it and what actions they would recommend. The process requires student groups to use their prior knowledge to come to a decision. During these discussions the group will identify the theory and knowledge needed to deepen and develop their understanding of the problem. The group agrees a research programme of learning objectives in the subject discipline, for all members into the relevant aspects of the subject discipline, so that at the following meeting they can revise their decision as appropriate. Each group has their own tutor, whose role is to facilitate the group work (Schmidt et al, 2009; Ungaretti et al, 2015). An important part of this role is the provision of subject theory and knowledge through personal comment and recommendation of appropriate learning resources.

The method started life in the 1960s (Loyens et al, 2011) and has been widely applied in medicine. We can see the debt to medical teaching in the emphasis on students' analysis and understanding of an authentic 'real-life' practical case, which lies at the heart of the method. It has had some success in higher education institutions such as Maastricht University in the Netherlands (Vardi and Ciccarelli, 2008; Schmidt et al, 2009) with a growing perception of the potential value for the teaching of management subject disciplines (Smith, 2005; Daly et al, 2012; Ungaretti et al, 2015; Maddox et al, 2018). Much is claimed for this approach to teaching. It is held to increase student engagement and motivation to learn subject knowledge. It does this by facing them with a clear job related, real life problem similar to those that they might have to deal with in their work career, and then providing tutorial support for their search for and use of the discipline theory that will help them manage the decisions raised, effectively. By this process, students and teaching staff exercise joint control over the student learning process. Several additional skills are developed alongside the subject knowledge on which the case is based. Through the group discussions students develop greater competence in social and cognitive skills, such as collaboration, problem solving, critical thinking, self-directed learning, verbal presentation and self-presentation (Loyens et al, 2011; Vardi and Ciccarelli, 2008; Schmidt et al, 2009). 


\subsection{Implementation of PBL courses}

The perceptions of students on problem-based courses and the staff teaching them are generally positive (Loyens et al, 2011; Daly et al, 2012; Schmidt et al, 2009; Maddox et al, 2018 ). Surveys of their experiences show enthusiasm for the approach, with students in particular appreciative of the quality of informal and formal contact with staff. However as Ungaretti at al (2015) point out PBL should not be considered as a substitute for other pedagogies but as a complement to them. The goal is to combine this approach appropriately with other teaching methods and to do it well. The benefits cannot be obtained without effective implementation and this involves extensive preparation. According to Ungaretti et al (2015) teaching a successful PBL management module demands the effective management of the following factors:

- Course administration and logistics of delivery

- Problem (case) development

- Faculty and tutor preparation

- Design of student assessment measures

- Student preparation

- Evaluation of the learning achieved

Such a course typically introduces practical organisational challenges. It is much more straightforward to address a cohort of students who are all together in a lecture theatre than to divide them into teams, or to allocate them to tutorial groups, and to set, administer, and evaluate a series of practical activities. The larger the student cohort the greater the number of student groups and hence tutors. The group of tutors also require organising as they must be seen to act in concert on key issues such as standard of marking. Regular meetings of the tutor group are necessary both before and during the delivery of the module.

For many practitioners the success of PBL rests to a large extent on the quality of the design of the case problem and the skills of the tutors (Loyens et al, 2011; Schmidt et al, 2009). With respect to the case problem design Loyens et al (2011) building on the seven principles for case design proposed by Dolmans et al (1997) have developed five design 'rules'. A PBL case problem should build on prior knowledge (of the students), elicit discussion (by the student group), stimulate self-directed learning (through the implicit and explicit learning issues posed), encourage knowledge integration and transfer (with students pre-existing knowledge) and be relevant to the students' future profession. For a business discipline this poses a challenge - developing a case based on a real life business that students can understand and analyse, which poses ill-structured problems but does not involve too complex a business scene (too many products or services). Moreover such a case will require regular updating or replacement as business conditions change.

The tutor role is demanding in that he or she is expected to facilitate the group discussions, ensure that the subject discipline issues and the case material are both considered in the appropriate depth and to assess each group member for their individual contribution. Moreover where the level of structure provided by course materials and/or student prior knowledge is not adequate for the cohort, it is to the tutors that the group turns to help them manage the problem (Schmidt et al, 2009). Although it is accepted that each group session will be unique to the student group, the sessions need to cover similar ground and the tutors need to be seen as acting collaboratively and consistently, marking (where required) to a similar standard. To carry out this job, the tutor needs subject knowledge, facilitation skills and a positive attitude towards collaboration with fellow tutors. Academic staff can be relied on for subject knowledge but are less likely to be familiar with or have the other skills (Ungaretti et al, 2015). Hence some time may be necessary for training the tutors in the method.

Moreover evaluating and marking students on a PBL course, largely the responsibility of the tutors, is significantly different from the process adopted by traditional lecture based courses. The concern is more on the quality of student interactions and discussion than the final output of decisions and reports. Tutors will be assessing individual students on how they approach applying theory, the contribution to the team's work, the knowledge and skills demonstrated during the session as well as the quality of any report submitted. This all puts a greater responsibility and work load onto tutors.

The student groups' response to this type of teaching is key, just because the learning outcomes depend so critically on the student cohort's contribution and behaviour as a group. This teaching method poses a challenge for first year business students. As the previous section has shown, few if any will have encountered 
this type of learning method before. It requires a radical shift in their approach to their own learning, which will be particularly acute when other modules in the degree course are taught by more traditional methods. To students, by comparison with a pedagogy based on lectures 'PBL looks hectic, disorganised, and even chaotic' (Ungaretti et al, 2015, p179). The quality of their learning as individuals and as a group depends on the functioning of the discussion groups. Ineffective, unproductive student group meetings can lead to the perception that their learning time is wasted (Daly et al, 2012). But this is exactly the concern identified by teachers of PBL courses (Vardi and Ciccarelli, 2008). Potential problems include:

- Dysfunctional student groups with members that do not prepare properly or fail to contribute to the class activities and/or where disruptive conflict occurs.

- Unhelpful individual student behaviour including the proposal of new ideas with little relevance to the problem, an apparent lack of clarity about the learning objectives, the production of research results irrelevant to the problem or subject, inadequate levels of subject study.

Vardi and Ciccarella (2008) report on how these problems were successfully addressed in the design of a PBL course, but in the process show how much more work in course preparation and delivery, was required to combat them.

There are a set of well understood tools for evaluating student response, but it can be more difficult to establish the level of learning achieved. In the first year such activities can prepare students for later stages of their studies or for their future employment, and the true measure of success is either their eventual career trajectory or their ability to apply themselves to later stages of their course. Much of the research into the value of PBL on student learning, has been its use in medical education (Loyens et al, 2011; Schmidt et al, 2009; Ungaretti et al, 2015; Smith, 2005). The standard approach is to compare the learning achieved by two student cohorts, similar in all relevant characteristics, taught the same subject but one by traditional methods and the other by PBL methods. The measures of achievement include both hard measures such as medical knowledge tests and softer ones of student self-assessments after having completed their courses and started practising as medics. The weight of evidence of these studies supports a small positive effect in almost all of the claimed benefits including clinical knowledge, diagnostic ability and communicating and cognitive skills.

Studies comparing PBL in medicine with management suggest that similar benefits should be achievable for other disciplines (Ungaretta et al, 2015; Smith, 2005).

This type of teaching has an intuitive attraction in terms of the actual process of learning and the expected learning outcomes - in particular practical business and management skills. It is popular with staff and students when well done. Research evidence identifies a small but significantly positive learning benefit in both subject knowledge and management and cognitive skills development. But it is also resource heavy in terms of teaching staff.

\section{The Critical Thinking module for Cass $1^{\text {st }}$ year Business Management students - BM1102}

This module was part of the redesign of the Business Management degree course at Cass initiated for the 2018-2019 academic year. The first year of the redesign was delivered to a cohort of 360 students drawn from over 40 countries world-wide. Students study eight modules during the academic year - four in the first term and four in the second. Under the redesign the subjects taught in the first year are:

$\left(1^{\text {st }}\right.$ term) introduction to management and organisational behaviour, economics, marketing, and critical thinking for business,

$\left(2^{\text {nd }}\right.$ term) quantitative methods and analytics, operations and supply chain management, introduction to accounting, and managing complexity and business skills

The Critical Thinking module was delivered in the first term of the new intake. The core design is based on the concepts of Problem Based Learning and this was the only module using PBL methods, during the first year. 


\subsection{Module aims, subject knowledge and research skills}

The stated educational aims are to develop critical thinking skills. Specifically the module aims to develop students' understanding of 'what is going on in any given situation through the use of reasoning, the evaluation of evidence and self-reflection on their own thinking processes' (Critical Thinking in Business handbook, 2018). The key concepts on which reasoning and critical thinking are based are presented in the course text book ('Critical Thinking' by Chatfield, 2018) with a wealth of fascinating examples. This forms the core knowledge for the module. Students are expected to read the whole of this book over the course of the module. It is split into 2 parts. The first part deals with the basic theory of reasoning and logic. The second part entitled being reasonable in an unreasonable world introduces the concepts of rhetoric and bias. Chatfield gives a definition of critical reasoning highly relevant to research skills, 'when we are thinking critically, we are setting out actively to understand what is going on by using reasoning, evaluating evidence and thinking carefully about the process of thinking itself' (Chatfield, 2018, p6). Students are expected to develop their own reasoning skills by applying the ideas in the book, chapter by chapter, to the business case written for the module.

The choice of a PBL approach for this module is particularly appropriate. The three cognitive and social skills of greatest relevance and importance to research, identified in section 2 - the ability to work independently setting own goals, to think in a clear, logical and critical way and to communicate the results effectively, are all skills developed by PBL teaching methods. The module's subject knowledge of Critical thinking, supports and reinforces students understanding of the skills of critical thinking.

\subsection{Course design and organisation}

The module was taught through ten weekly student group sessions and one introductory lecture. Students were organised into small groups and assigned a group tutor for the term. There were nine tutors- three faculty members and six PhD students. Before the course commenced, the three faculty members spent between 60 - 80 hours, in several preparatory meetings and tasks designing the module. This included developing original content with a real business case, preparing the weekly problem tasks, the tutor guides, understanding the problem-based learning technique and selecting an appropriate reference source on the subject knowledge, for the students.

Each tutor had either 2 or 3 tutor groups, depending on their time availability. Each tutor group had between 12 to 16 students. The students were pre-allocated to the tutor groups keeping in mind the importance of obtaining a suitably balanced distribution with respect to nationality, gender, and stream in the undergraduate program. All the materials and documentation for the module were delivered to students via the VLE Moodle. This was of particular importance for the handling of the case. The case was built up week by week with additional information given on the company's developments over time. A new set of questions was set on the case reflecting the situation reached by the company. This new case material and questions were published on Moodle each week ahead of the relevant group discussion session.

\subsection{Managing the student group sessions}

The ten tutorial sessions were structured by the faculty design team, who developed the case material and the questions on the case for discussion and decision. However, the actual functioning of the tutorial was managed by the student group - the students responsible for leading and recording the session and the group's assigned tutor.

The student groups set their own learning goals each week, which could be modified by the tutor. They were based on each week's company case problem and the relevant chapter set from Chatfield's book (both of which they should have read prior to the session). The group was expected to identify the case's current problem, brainstorm possible solutions, determine what knowledge was lacking within the group and then decide learning goals together. During the following week, each member was responsible for addressing the learning goals, so as to come to the following week's session ready to share their learning and review and perhaps change the solutions proposed for the previous week's problem. Hence each tutorial session had two parts: the first part dealt with the previous week's learning objectives and case decisions. In the second part the group went on to deal with the week's new case problem and to set the next set of learning objectives. 
There were three student roles: The discussion leader, the secretary - who is a note takes, and discussion participants. Every student member of the group was allocated the leader role for one session together with a partner and the secretary role for another session. The tutor's role could vary somewhat depending on the group's profile and needs. He or she acted as coach to each leader and reporter and intervened as appropriate to ensure that the key textbook (Chatfield, 2018) knowledge set for the session was addressed directly by the group. The team of tutors agreed to interject at least one common learning objective for each week based on the week's text book chapter.

The students received oral feedback about their performance every week. Typically, this would be in the form of one or two sentences from the tutor, but more importantly as part of critical thinking, this could also be from their peers. While most of the students were hesitant to give feedback to each other in the first few weeks, by the latter weeks they were significantly more likely to give as well as receive feedback from their group members. The tutor also gave oral feedback to the discussion leaders for that week. This would typically be more detailed, lasting on an average five minutes per person. In the spirit of critical thinking the students also had the opportunity to give feedback to the tutor as well as suggestions on how to improve the module in the final week.

The tutors met formally every week on Monday to prepare for the week's tutorial. In this meeting the tutors would often agree on a common approach for handling any student problem. While there were no major student problems in the module, it was nevertheless useful to have a common response to the usual issues such as late arrivals, not coming prepared to a tutorial, and not participating adequately. Typical responses or interventions from the tutor included speaking to the individual separately, give some feedback, and encouraging them to take a more active role in the discussion.

\subsection{Case problem}

The case used for all the 10 sessions was designed specifically for this module. It was based on Hailo, a taxi app launched in London in 2012 which then went through several highs and lows over the next few years. The case closely mirrors what happened in the early years but adds a few wrinkles to the basic story to fit the needs of the course. Every week, the student group was confronted with a problem that Hailo also had to face, for which there was no clear answer. Each week's problem expanded their knowledge of the company and its senior executives. How the company actually handled the problems posed was published the following week as part of the ongoing description of the company's operations. Short video clips showing the founders and senior executives describing actual developments, were placed on the VLE, Moodle.

The case problem met the five criteria required for PBL (Loyens et al, 2011). It is based on 4-5 years operation of a real commercial company hence is relevant to the students' career aspirations in business. It builds on their prior interest in and general knowledge of the way markets and companies work and develops their knowledge further by detailing the actual way that one company handled its start-up and early development years. The way in which the case material is developed week to week maintains the interest of the students. This steadily develops greater understanding of the company and forms the basis for different types of discussion at each week's session, generating ever greater interest and discussion over the term. The questions set each week, relating to both the company and the thinking process stimulate self-directed learning.

\subsection{Tutor preparation}

Problem-based learning was a new experience for all but one of the nine tutors. All attended a training session with a tutor from Maastricht University on problem-based learning which included a briefing about the objectives of the module, and module administration. These hours spent together in designing, training, and briefing were crucial in ensuring a consistent message and learning experience for the students across the tutor groups. Since the tutors carried out all the marking, kept the group sessions on target and provided oral feedback to the group members, it was important that they agreed a common marking scheme and approach to directing the weekly sessions.

During the module, the tutors regularly met twice every week for informal debriefing session so as to share ideas and best practices across the tutor groups. Every Monday, all the tutors would meet for an hour to discuss the task for that week, the learning objectives, and details about the roles and expectations from the tutor. Together, the tutors would go through the tutor's briefing document. These weekly meetings were 
central in ensuring a common approach in all the tutor groups. As most of the tutorial sessions were scheduled in parallel on Fridays, the tutors settled into a pattern of an informal debriefing session at a local café on Friday evenings. The informal debriefing session was also useful in sharing ideas and best practices across the tutor groups while these thoughts were fresh in everyone's mind. In retrospect, the Friday discussion also helped to make the preparatory meetings on Mondays more effective. With the benefit of hindsight, the preparation that the tutors put into the module, while demanding, was central in creating the student experience.

\subsection{Course assessment}

Students were required to attend all sessions. The assessment was composed of a mark for:

- Attendance and quality of participation in class

- Effectiveness in handling the leadership role

- An individual essay on a topic related to the Hailo case, to be submitted after teaching of the module had been completed

There was no formal written examination.

The nine tutors' individual responsibility for marking the student's weekly contribution in the classes raised the issue of the potential for variation in the marking pattern between tutors. To address this potential issue, a simple four-point template was designed where each level was qualitatively described for the tutor. For instance, a student was to get 1 out of 4 in a tutorial if the student arrived late (more than 10 mins late to class is to be marked absent) or was rude to colleagues or disrupted the discussion. A student would get $4 / 4$ if the student came on time and well prepared, made at least 2 good contributions to the discussion, was collegial, and built on other students points. After 5 weeks, each tutor's weekly score was aggregated. Using a simple rule, the students were then sent a summary of their performance as participants till that point, and some tips on how they could do even better. This mid-point feedback was useful in reinforcing the importance of preparation and meaning participation.

\subsection{Student preparation}

The preparatory work for the students was extensive. It involved four steps. First, all the students attended a lecture in which the module leaders and all the tutors were introduced. The students were briefed about what is critical thinking and what to expect in the module especially the context of the Hailo case. Second, the students were directed to Moodle to watch two videos: (i) On the need for critical thinking skills and (ii) On the problem-based learning methodology, the different roles, and the overall pedagogical approach. Third, the students were given details instructions and readings on the problem-based learning methodology. And finally, in the first tutorial, the tutor performed the role of the discussion leader and secretary that enabled the students to see the main roles and expectations from these roles in action.

\subsection{Course evaluation and implications for the next delivery of the module}

Student performance in terms of pass rates was good- 351 of the cohort of 360 (97.5\%) passed, leaving a small group to do resit coursework in the summer. Gathering feedback from both students and teaching staff has been a key part of the development process. One unexpected challenge has been that the university's core processes for gathering student feedback are heavily oriented towards a lecture format, and also heavily oriented towards a highly modularised curriculum where a lecturer, or on occasions a small team of lecturers, delivers a largely free-standing sequence of lectures over a number of weeks. For the critical thinking module delivered by problem based learning it was nevertheless feasible to build in an online evaluation process which focused on the benefits or otherwise of learning in small groups.

Student feedback was gathered through a number of channels. These could be categorised as:

1. Written feedback on the module itself: students completed an overall module evaluation form which was in line with the university's standard policy, and also the online tutorial evaluation form which as already observed was better aligned with the requirements of a module taught through PBL

2. Oral feedback on the undergraduate course as a whole. This was gathered through staff-student meetings and also through a series of focus groups 
3. Informal feedback gathered through discussions with students throughout their first year. This included points raised at meetings with personal tutors, and also at meetings between first year students and second years who were able to act as mentors. These proved a fruitful source of understanding of how the first year students' learning processes were working

Student feedback regarding the group activities was generally supportive, commenting favourably on the level of engagement, the extent to which it had facilitated their own thought processes, and the support that they received from tutors. But a significant minority felt that the approach worked less well for them than conventional lectures. Others quite reasonably expressed concern that a format which depends on significant participation and input from students does not work effectively for those who are very introverted or who have other difficulties in communication. More detail on student responses is shown in the appendix

Feedback from staff who participated on the module has been positive. Some of them pointed out that it is at times difficult not to intervene in a discussion immediately and let the students figure something out on their own, or that one must continuously encourage the students to self-govern the group dynamics, for instance by calling out individuals if they have not come prepared for the tutorial. But just like the students who developed into more critical thinkers by the end of the term, the tutors have also become more adept at running problem-based-learning sessions. If agreeing to come back to do the next year's module is an indication of the tutor's overall feedback, it is worthwhile knowing that of the nine tutors all but one would be participating in the module for the next academic year. The only one who would not be participating is close to finishing her $\mathrm{PhD}$ and therefore is occupied.

The timing of the module within the first part of the academic year afforded the opportunity to carry out some redesign in preparation for its delivery for the second time. Issues which were addressed through these changes could be divided into two broad categories:

- The practical and logistic challenges associated with dealing with a large cohort working as a multiplicity of small groups.

- The pedagogic approach and its fit with other modules and with students' expectations. For example some students were uncomfortable with an approach which was focused on thinking and reasoning techniques and not on internalising a body of knowledge. Others engaged with this principle but felt that a different case or different textbook would have been more appropriate

Key characteristics of the redesigned module to be delivered in the next academic year (2019-20) include a slight increase in the amount of lecture content to allow the key concepts to be framed more clearly and presented to students in the context which emphasises why they are important. The assessment process has been revised to reduce the opportunities for academic misconduct as the original approach was, at least in principle, open to 'contract cheating' where students pay for essays to be written to order. This has entailed the introduction of an exam at the end of the students' first term. Nevertheless the inclusion of an assessment of participation as a central part of the module is being retained. The title of the module was amended from 'Critical Thinking' to 'Critical Analysis for Business': inclusion of a reference to business in the module title and addition of two more lectures, one at the mid-point of the module and one towards the end, were direct responses to comments from students within online feedback.

Arguably some of the most important outputs from the module were learning for the course team as a whole and for the tutors who participated, in that the tutors gained valuable pedagogic skills and the course team were able to gain and act on experience in how to build complex and participative activities into a large-scale undergraduate course.

\section{Conclusions}

The module clearly focuses on developing both critical thinking and some of the personal skills which are important for not only empirical business management research or the business degree but also for business management employers in general. These are skills that, if internalised by first year students, will help them with the transition to university as well as in subsequent years of their undergraduate studies and in the ir future careers. The problem-based learning structure poses challenges for both teaching staff and students. 
The success of this type of course depends on a number of factors, of which efficient organisation, student presence at and active participation in class and a common agreed approach to class interventions by tutors are perhaps the most important. Individual student 'buy in' is critical to the learning of the student group as a whole. The mixed response of students to the module highlights the importance of 'selling' the module more effectively to them. There are also indications that for some students it is important to provide further 'scaffolding' for the module, for example to encourage participation from those who regarded themselves as introverts or who had language difficulties. The delivery of this module in the next academic year stands to benefit greatly from this first experience of teaching using problem-based learning methods.

The authors would like to acknowledge the innovative work carried out by Prof. Caroline Wiertz, Prof. Andre Spicer and Dr. Aneesh Banerjee in the design and implementation of the new module of Critical Thinking for the redesigned Business Management Degree at Cass Business School.

\section{References}

Barnett R and Hallam S (1999) Teaching for supercomplexity: a pedagogy for higher education in Mortimore $P$ Understanding pedagogy and its impact on learning London: Paul Chapman Publishing

Boddy David (2017) 'Management an Introduction' $7^{\text {th }}$ ed. Pearson

Bryman Alan (2016) 'Social research methods', $5^{\text {th }}$ edition, Oxford University Press, Oxford

Bryman Alan \& Bell Emma (2015) 'Business Research Methods' 4th edition

Chatfield T (2018) Critical thinking: your guide to effective argument, successful analysis, \& independent study London, Sage

Critical Thinking module handbook - BM1102 (Autumn 2018)

Daly P S, White M M, Zisk D S and Cavazos D E (2012) Problem-Based Teaching in International Management: A Political/Economic Risk Assessment Exercise. Journal of Teaching in International Business 23:4 260-276

Dolmans, D. H. J. M., Snellen-Balendong, H., Wolfhagen I. H. A. P., \& Van der Vleuten, C. P. M. (1997). Seven principles of effective case design for a problem-based curriculum. Medical Teacher, 19, 185-189.

Dreyfus, H., \& Dreyfus, S. (1988). Mind over machine: The power of humanintuition and expertise in the era of the computer. New York: Free Press.

Mark Easterby-Smith, Richard Thorpe and Andy Lowe (1995) 'Management Research an Introduction' Sage publications Ltd

Mark Easterby-Smith, Richard Thorpe, Paul Jackson and Andy Lowe (2018) 'Management and Business Research' $6^{\text {th }}$ edition, Sage publications Ltd

Goodyear P and Dimitriadis Y (2013): In media res: reframing design for learning. Research in learning technology 21

Hill, Linda (1992) 'Becoming a Manager: Mastery of a new identity' Harvard Business School Press, Boston

Land R (2016) Toil and trouble: threshold concepts as a pedagogy of uncertainty, in Land R, Meyer J, and Flanagan M: Threshold concepts in practice Rotterdam: Sense Publishers

Loyens, S. M. M., Kirschner, P. \& Paas, F. (2011). Problem-based Learning. In K. R. Harris, S. Graham \& T. Urdan (Eds.), APA Educational Psychology Handbook: Vol 2 (p. a). Washington: American Psychological Association; at Research Online an open access institutional repository for the University of Wollongong

Maddox L, Patino A, Kaltcheva V and Pitta D (2018) Integration of an online Curriculum with a Real-Life Exercise: A step beyond Traditional Classroom Teaching; Journal of Advertising Education vol 22(1) 23-33

Maunder R, Cunliffe M, Galvin J, Mjali S, and Rogers J (2013) Listening to student voices: student researchers exploring undergraduate experiences of university transition. Higher education 66 (2) 139-152

Ozturk C, Muslu G K and Dicle A (2008) A comparison of problem-based and traditional education on nursing students' critical thinking dispositions Nurse Education Today 28, 627-632

Robinson S, Hope D, and Holyoak L (2013) Can we meet their expectations? Experiences and perceptions of feedback in first year undergraduate students. Assessment and evaluation in higher education. 38 (3) 260-272

Saunders Mark, Lewis Philip, and Thornhill Adrian, (2015) 'Research Methods for Business Students' $7^{\text {th }}$ edition, Pearson Education Ltd

O’Donovan B (2010): Filling a pail or lighting a fire: the intellectual development of management undergraduates. International journal of management education 9 (1) 1-10

Schmidt, H. G., Van der Molen, H. T., Te Winkel, W. W. R., \& Wijnen, W. H. F. W (2009). Constructivist, problem-based learning does work: a meta-analysis of curricular comparisons involving a single medical school. Educational Psychologist, 44, 1-23.

Smith G F (2005) Problem-bases Learning: Can it improve Managerial Thinking? Journal of Management Education vol 29 (2) $357-378$

Thomas I (2009) Critical Thinking, Transformative Learning, Sustainable Education, and Problem-Based Learning in Universities. Journal of Transformative Education 7(3) 245-264

World Economic Forum, (2018), 'The future of jobs report'. Insight Report, World Economic Forum, Geneva. [Accessed from http://www3.weforum.org/docs/WEF_Future_of_Jobs_2018.pdf]

Wright A (2019), 'Critical thinking is in critical condition', Times Higher Education 25 July, pp26-27

Ungaretti T, Thompson K, Miller A and Peterson T (2015) Problem-Based Learning: Lessons From Medical Education and Challenges for Management Education. Academy of Management Learning \& Education vol14(2), 173-186Wright A (2019, 'Critical thinking is in critical condition' Times Higher Education 25 July pages 26-27 
Vardi, Iris and Ciccarelli, Marina, (2008), 'Overcoming problems in problem-based learning: a trial of strategies in an undergraduate unit', Innovations in Education and Teaching International; 45, 4; p345-354

\section{Appendix - Summary of Student feedback on the critical thinking module}

\begin{tabular}{|c|c|c|c|c|}
\hline \multicolumn{2}{|c|}{ Source of feedback } & \multirow[b]{2}{*}{$\begin{array}{l}\text { Approach to teaching } \\
\text { Students appreciated 'active } \\
\text { learning' and being 'pushed' to } \\
\text { participate. } \\
\text { Students welcomed the } \\
\text { opportunity to act as leaders at } \\
\text { stages in the module. } \\
\text { The lecturers and tutors } \\
\text { provided motivation, } \\
\text { There was a sense that } \\
\text { participants could speak freely } \\
\text { and express their views } \\
\text { However some students felt that } \\
\text { they would have benefited from } \\
\text { more guidance at the start on } \\
\text { what was expected of them }\end{array}$} & \multirow[b]{2}{*}{$\begin{array}{l}\text { Case material } \\
\text { Many students saw the } \\
\text { case material as highly } \\
\text { relevant - for instance it } \\
\text { gave them a sense of the } \\
\text { real issues encountered } \\
\text { by people within an } \\
\text { entrepreneurial business } \\
\text { However some felt that it } \\
\text { would be useful to include } \\
\text { a variety of cases and } \\
\text { were concerned that the } \\
\text { core case used had } \\
\text { become monotonous }\end{array}$} & \multirow[b]{2}{*}{$\begin{array}{l}\text { Group issues } \\
\text { Some students felt that the } \\
\text { role of the secretary was } \\
\text { unclear and did not recognise } \\
\text { the importance of taking } \\
\text { minutes accurately } \\
\text { There were concerns about } \\
\text { limited participation and } \\
\text { suggestions that more could } \\
\text { be done to ensure that every } \\
\text { group member took part }\end{array}$} \\
\hline $\begin{array}{l}\text { Written } \\
\text { feed-back } \\
\text { on module }\end{array}$ & $\begin{array}{l}\text { Module } \\
\text { evaluation }\end{array}$ & & & \\
\hline & $\begin{array}{l}\text { Tutorial } \\
\text { evaluation }\end{array}$ & $\begin{array}{l}\text { Positive comments that the } \\
\text { experience was relevant to the } \\
\text { sort of thing that students could } \\
\text { expect to experience once in } \\
\text { employment. } \\
\text { Interest in pursuing some of the } \\
\text { critical thinking issues in more } \\
\text { depth, for instance by studying } \\
\text { formal logic. } \\
\text { Mixed responses to the textbook } \\
\text { on Critical Thinking: some } \\
\text { students very much liked the } \\
\text { book and its approach whereas } \\
\text { others felt that it was not quite } \\
\text { right for this particular module }\end{array}$ & $\begin{array}{l}\text { Scope to expand or } \\
\text { rewrite some of the } \\
\text { problem tasks. } \\
\text { Potential for introducing a } \\
\text { second major case study } \\
\text { and comparing it with the } \\
\text { Hailo case. } \\
\text { Scope for more use of the } \\
\text { supporting video material } \\
\text { provided for the case. }\end{array}$ & $\begin{array}{l}\text { Concerns about the potential } \\
\text { to participate for students } \\
\text { who were introverted, who } \\
\text { had difficulty speaking, or } \\
\text { who had language difficulties. } \\
\text { Make time for students who } \\
\text { might be reticent and provide } \\
\text { more encouragement for } \\
\text { them to participate. }\end{array}$ \\
\hline \multirow[t]{2}{*}{$\begin{array}{l}\text { Oral feed- } \\
\text { back on } \\
\text { course }\end{array}$} & $\begin{array}{l}\text { Staff- } \\
\text { student } \\
\text { meetings }\end{array}$ & $\begin{array}{l}\text { Generally positive comments } \\
\text { about the relevance of the } \\
\text { module and the approach used. } \\
\text { In the context of the course as a } \\
\text { whole the students valued the } \\
\text { contrast with more conventional } \\
\text { lecture-based modules that they } \\
\text { took at the same time }\end{array}$ & $\begin{array}{l}\text { Positive comments about } \\
\text { the current nature and } \\
\text { relevance of the case } \\
\text { study. }\end{array}$ & $\begin{array}{l}\text { The benefits gained from the } \\
\text { module did depend } \\
\text { significantly on the group: for } \\
\text { example one participant in a } \\
\text { meeting felt conscious of } \\
\text { discussion being less } \\
\text { valuable than that in his } \\
\text { peers' groups because his } \\
\text { group contained a significant } \\
\text { proportion of students who } \\
\text { only made a minimal } \\
\text { contribution. }\end{array}$ \\
\hline & $\begin{array}{l}\text { Focus } \\
\text { groups }\end{array}$ & $\begin{array}{l}\text { Very positive observations on } \\
\text { the module notably because it } \\
\text { was perceived as something } \\
\text { which made this distinctive } \\
\text { compared to business } \\
\text { management courses at other } \\
\text { institutions. Positive remarks on } \\
\text { the value of small group learning } \\
\text { within a large cohort }\end{array}$ & $\begin{array}{l}\text { Students valued that the } \\
\text { case was fairly current } \\
\text { and that it could be related } \\
\text { to events taking place } \\
\text { over the past few years in } \\
\text { London. } \\
\text { Mixed reactions to video } \\
\text { material which some } \\
\text { students very much } \\
\text { enjoyed but others did not } \\
\text { necessarily engage with }\end{array}$ & $\begin{array}{l}\text { Observation that in tutorial } \\
\text { sessions - across the degree } \\
\text { course and not only in this } \\
\text { module - lack of attendance } \\
\text { and lack of participation } \\
\text { among some students was a } \\
\text { limitation }\end{array}$ \\
\hline \multicolumn{2}{|l|}{$\begin{array}{l}\text { Inform } \\
\text { al feedback }\end{array}$} & $\begin{array}{l}\text { Many students found the } \\
\text { transition to university and to a } \\
\text { new way of learning challenging. } \\
\text { While the training in critical } \\
\text { thinking was valuable, they also } \\
\text { needed time to adapt to an } \\
\text { environment in which they were } \\
\text { expected to carry out their own } \\
\text { analysis and where they could } \\
\text { expect to be assessed on the } \\
\text { quality of that analysis }\end{array}$ & $\begin{array}{l}\text { Students did revisit the } \\
\text { Hailo case used in the } \\
\text { critical thinking module at } \\
\text { later stages in the course } \\
\text { and this did provide } \\
\text { opportunities to build } \\
\text { connections between } \\
\text { different elements of the } \\
\text { course. }\end{array}$ & $\begin{array}{l}\text { The most significant problems } \\
\text { with groups seemed to be } \\
\text { with non-participants rather } \\
\text { than with difficult dynamics } \\
\text { between active participants }\end{array}$ \\
\hline
\end{tabular}

